\title{
Distribution and habitat preferences of Sumatran elephant (Elephas maximus sumatranus) in Riau, Indonesia
}

\author{
YOHANES WISHNU SUKMANTORO ${ }^{1, \vartheta}$, HADI S. ALIKODRA ${ }^{1}$, AGUS P. KARTONO ${ }^{1}$, EFRANSJAH ${ }^{2}$ \\ ${ }^{1}$ Department of Tropical Biodiversity Conservation, Faculty of Forestry, Bogor Agriculture Institute, Jl. Lingkar Akademik Kampus IPB, Dramaga, \\ Babakan, Dramaga, Bogor, Jawa Barat 16001. Tel/Fax.+62-252-8621947, ’email: wishnubio74@gmail.com \\ ${ }^{2}$ Senior advisor of Minister of Environment and Forestry, Indonesia Republic, Gedung Manggala Wanabakti Jln. Gatot Subroto-Senayan Jakarta- \\ Indonesia-10207. Tel/Fax: +62-21-5704501-04; +62-21-5730191
}

Manuscript received: 21 June 2018. Revision accepted: 24 December 2018.

\begin{abstract}
Sukmantoro YW, Alikodra HS, Kartono AP, Efransjah. 2019. Distribution and habitat preferences of Sumatran elephant (Elephas maximus sumatranus) in Riau, Indonesia. Biodiversitas 20: 226-235. The research on elephant distribution and habitat preference was carried out in two locations Balai Raja and Tesso Nilo, Riau Province, Indonesia on 2012-2016. Three GPS Collars were installed on one individual adult female at Balai Raja (Desma) and two individuals at Tesso Nilo (Angelina and Butet). For the elephants' habitat, the forest cover identification was performed by spectral color analysis on the 8 ETM+ Landsat images and resulted in land cover detail on MCP (Minimum Convex Polygon), and 50\% and 95\% fix kernel density of movement of the elephant including in the morning, the day and the night. Based on MCP estimation, Desma habitat area was $328.86 \mathrm{~km}^{2}$, while Angelina and Butet were $632.57 \mathrm{~km}^{2}$ and $701.60 \mathrm{~km}^{2}$, respectively. Land cover in MCP indicated that the oil palm, mixed agriculture, and rubber were dominantly areas used by Desma, while acacia, forest and oil palm plantation were dominantly area used by Angelina and Butet. In habitat preferences, Desma preferred forests and swamp areas to day activity. However, Angelina and Butet selected acacia plantation, forest, infrastructures such as the mills and land opening as the location of movement. Water bodies and shrub were not widely used for the elephants' activities. This study indicated that the pattern of habitat selection is a strategy for elephants to avoid conflict with the human. Although resources are limited, the habitat selection can reduce conflict incidence
\end{abstract}

Keywords: Coloring spectral analysis, habitat preference, Riau, Sumatran elephant

\section{INTRODUCTION}

Sumatran elephant (Elephas maximus sumatranus Temminck, 1847) is one of the three sub-species of Asian Elephant which is as one of the priorities of wildlife of Sumatera Island by Indonesia government policy. This species has been categorized as critically endangered (CE) according to the IUCN on 2012. In Sumatra, the populations and habitats of this elephant are in the critical stage. In 1985, the population of this species was between 2400-4800 and then decreased to between 2400-2800 elephants in 2007. By 2014, the population was estimated to become only 1724 elephants (Suhartono et al. 2008; Azmi and Gunaryadi 2011; WWF Indonesia 2014). While, in Riau, the elephant population was 1067 to 1647 individuals in 1984-1985 (Blouch and Simbolon 1985). By 2016, the estimated population of Sumatran elephant in Riau was only 244-338 individuals (Desai and Samsuardi 2009; Riau elephant workshop results in 2016 unpublished).

The population of Sumatran Elephant is drastically declining in Riau caused by deforestation by plantations or monoculture concessions and community settlements (Desai and Samsuardi 2009; Sukmantoro et al. 2011). Currently, $85 \%$ of the elephants' distribution in Riau is outside the conservation area and not in its natural habitat, which is divided into production and conversion areas by companies or communities, i.e. $67 \%$ and $12 \%$ protected forest. The remaining $6 \%$ is outside the forest area (Sitompul et al. 2013, Sukmantoro et al. 2013). Changes in habitat conditions can lead to the change in the distribution and imbalances of elephant life (William and Johnsingh 1996; Lin et al. 2008).

As a result of habitat loss and fragmentations, the conflict between humans and elephants are now widespread. The conflicts occur mainly caused by elephant crop raiding. Human-elephant conflicts left injuries and in some instance, death not only for elephants but also humans (Desai and Riddle 2015; Mishra et al. 2015; Senthilkumar 2016).

Habitat distribution and preference studies can be a measure in answering wildlife geographical range and wildlife-habitat relationship and management strategies (Beyer et al. 2010). Research on distribution and habitat preference for the Sumatran elephant in Riau is particularly important to be able to determine the current distribution and selected habitat use of this species as a result of landscape changes and as a strategy for recovery of populations and their habitats. In this study, elephant distribution and habitat preference were carried out in three targeted elephant groups, two elephant groups in Tesso Nilo (Angelina and Butet group) and the other one in Balai Raja (Desma group), Riau Province. 


\section{MATERIALS AND METHODS}

\section{Distribution and movement of elephants with GPS Collar}

The research was carried out at Balai Raja (coordinate $=$ $1^{\circ} 1^{\prime} 30^{\prime \prime}-1^{\circ} 23{ }^{\prime} 30^{\prime \prime} \mathrm{N}$ and $\left.101^{\circ} 2^{\prime} 30^{\prime \prime}-101^{\circ} 19^{\prime} 30^{\prime \prime} \mathrm{E}\right)$ and Tesso Nilo (coordinate $=101^{\circ} 33^{\prime} 00^{\prime \prime}-101^{\circ} 51^{\prime} 36^{\prime \prime}$ E and $\left.00^{\circ} 01^{\prime} 48^{\prime \prime} \mathrm{N}-00^{\circ} 17^{\prime} 24^{\prime \prime} \mathrm{S}\right)$, Riau Province. In this study, the data collection was the elephant movement through the use of the GPS Collar. Three GPS Collars were installed on oneindividual adult female at Balai Raja (Desma) and two individuals at Tesso Nilo (Angelina and Butet) from 2012 to 2016. The installation team consisted of a preliminary survey team, some people did anesthesia, a vet; two people measured elephant morphometrics and the others secured catch sites from the other wild elephants. GPS Collars were installed and monitored by the monitoring team through the website www.awetelemetry.com and assisted through field checking by the elephant patrol team. Arcgis is used to describe the results of data collection in vector and based on time and distance of elephant movement.

\section{Land cover review}

Analysis of land cover was done by using a spectral remote sensing technique with bands 1-8 Landsat 8 etm + and the accuracy of land cover with kappa coefficients. ArcGIS software was used in this study or assisted with ERDASS 2014 software to process raster data. Landsat 8 $\mathrm{Utm}+$ was downloaded from USGS Glovis (Rahman et al. 2004; Ardiansyah 2015).

The spatial data of the habitat use from MCP and kernel were re-analyzed by patching up with Landsat $8 \mathrm{etm}+$ land cover maps based on the spectral identification of the colors (reflectance) in bands 1-8. Each color in the satellite image indicated the difference in spectral values in bands 1-8. The difference in value indicated land cover of the garden, forest, open land, shrub or grass based on the value of each band. After the spectral (reflectance) value was generated, then a field check was prepared to ensure the accuracy of the land cover data based on the spectral value. Checking of location was based on the number of land cover that had been identified. The more visited each land cover, the better. Then the data were analyzed with the Kappa coefficient to determine the percentage of accuracy and improvement step (de Souza et al. 2013). The use of spectral colors and field checks confirmed more accurately than land cover in Landsat imagery.

\section{Data analysis}

Distribution and movement of elephants were performed in an analysis of distribution patterns and movements of the three female elephants that installed by the GPS Collar. Pearson correlation test was used to see the trend pattern of movement distance. The number of samples that the data distribution of the GPS Collar elephant (Desma) in Balai Raja Raja was 2028 samples (N $=2028$ ). In Tesso Nilo, Angelina elephant encountered to 995 samples $(\mathrm{N}=995)$ and from Butet elephant was 1027 samples $(\mathrm{N}=1027)$. The data analysis was begun by calculating the percentage of the land cover area in MCP and fix Kernel 50\% and 95\% in general and the elephants' distribution of Balai Raja (Desma) and Tesso Nilo (Angelina and Butet) based on morning, daytime and night time. Morning time was between 06: 00-07: 00, noon at 14 : 00-15: 00 and the evening is 20: 00-21: 00 . This study did not make a comparison in the season periods due to the irregular periods of the wet and dry season in 2014. Furthermore, according to the previous researches the season periods did not significantly affect the movement of elephants in Riau and southern Sumatra (Sitompul 2011; Sukmantoro et al. 2013), and assumptions this was also pertinent to GPS Collar data on 2012-2016.

Jacob's preferences index (D) was used to view habitat type preferences with Sumatran elephants. The formula D is $\mathrm{D}=(\mathrm{r}-\mathrm{p}) /(\mathrm{r}+\mathrm{p}-2 \mathrm{rp})$, $\mathrm{D}$ was the Jacob preference index, $\mathrm{r}$ was the proportion of habitat used, and $\mathrm{p}$ was the proportion of habitat available in Fix Kernel 50\% (Kauhalla and Auttila 2010). Jacob index values were between-1 to 1. Distribution of data checked with Kolmogorov-Smirnov test or ANOVA test for the normal data.

\section{RESULTS AND DISCUSSION}

\section{Elephant distribution and movement}

From the results of the study, total daily movements of Desma monitored by GPS Collar were 677 days with the habitat area in MCP is $328.86 \mathrm{~km}^{2}$, Angelina and Butet were each monitored by GPS Collar for 336 days (habitat area in MCP is $632.57 \mathrm{~km}^{2}$ ) and 332 days (the area of habitat in MCP is $701.60 \mathrm{~km}^{2}$ ). The three elephants tended to move between 0 and $3 \mathrm{~km}(87.6 \%$ Desma's movement between 0 and $3 \mathrm{~km}$ per day, $86.9 \%$ and $95.5 \%$ for Angelina and Butet, respectively). Pearson Correlation Test showed strong correlation of the movement distance (0.690.94) among them (Desma (p-value 0.338 in KolmogorovSmirnov Test), Angelina (p-value 0.506) and Butet (pvalue 0.167)). The patterns of Desma, Angelina and Butet's movements were aggregately concentrated in certain locations. The concentrated areas of their movements were based on a $95 \%$ and $50 \%$ fix kernel. In 50\% fix kernel, the total area of priority habitat used by Desma was $28.22 \mathrm{~km} 2$. For the width of Angelina and Butet priority habitat was $9.65 \mathrm{~km} 2$ and $16.24 \mathrm{~km} 2$, respectively.

\section{The reflectance value in the spectrum analyzer}

In Landsat 8 OLI + imagery, the total of the bands number was 11 and Band 1-8 were used in this study considered to be representative in the preparation of reflectance values interpreting the difference of land cover. The reflectance value also corresponded to the pixel value of the image or the digital number (Ardiansyah 2015). The calibration and transformation steps were performed to obtain suitable radian and reflectance values. To correct the reflectance value, land cover types were checked directly in the field or based on previous coordinate data about the land cover in fact by directly checking in the field, then check the reflectance value based on the coordinate data in the field. Kappa Coefficient is used to see how big the 
image deviation to the fact of land covers in the field (de Sousa et al. 2013).

From the characteristic of reflectance value on OLI + Landsat image, band value 1-4 tended to be low then raised in band 5 and then dropped back in band 6-8 (Figure 1). This value was different with Landsat image 7 OLI + where the reflectance value of band 1-3 was low and the highest band was 4 (Sukmantoro et al. 2014). Low reflectance values in bands 1-4 were seen for all land cover variables. Significant differences in band values were seen in bands 5 to 7 where respective land cover could be seen in different. In the $8^{\text {th }}$ band, the reflectance value was almost equal in each variable of land cover. In infrastructures (public buildings, factories or buildings) and settlements, it had the highest in band 7. The lowest was in bands 5-7 is water bodies.

The reflectance value for each land cover was the final result of land cover confirmation factually in the field through kappa coefficient data from Sukmantoro et al. (2014) and data collection of infrastructure including settlement and land cover in Balai Raja and confirmation of reflected data that had not been obtained, namely acacia cover in Tesso Nilo. The previous reflectance data could not be used because of differences in the value used, the use of different image types, i.e. Landsat 7 ETM + (previously used) and streaming the map so that band $6 \mathrm{~s}$ relatively unusable, the number of bands is limited. The result of the kappa coefficient to confirm the reflectance value to the truth of the value to the factual conditions in the field.

The total of the checkpoint of water bodies in the field (number of checkpoints $=18$ points) was no deviates from other land covers. Shrubs with the number of checkpoints were 7,3 of which deviate toward other land covers that was the swamp of its reflectance value for the bush and 1 sample leads to the rubber. Of the total number of checkpoints s 99 points, the number of deviations is 20 points, so the percentage of truth between the reflectance value for land cover and the direct check of the field based on the kappa coefficient formula in xlstat was 0.774 (status was good).

Table 1. The reflectance values of Band 1-8 for each type of land cover in Balai Raja and Tesso Nilo, Riau, Indonesia

\begin{tabular}{lcccccccc}
\hline & B1 & B2 & B3 & B4 & B5 & B6 & B7 & B8 \\
\hline BA & 0.2028 & 0.1752 & 0.1438 & 0.1170 & 0.1861 & 0.0728 & 0.0358 & 0.1333 \\
SMK & 0.2011 & 0.1722 & 0.1399 & 0.1067 & 0.3468 & 0.1751 & 0.0741 & 0.1279 \\
HT & 0.2019 & 0.1730 & 0.1396 & 0.1080 & 0.3000 & 0.1393 & 0.0550 & 0.1275 \\
KR & 0.2001 & 0.1713 & 0.1386 & 0.1064 & 0.3432 & 0.1909 & 0.0789 & 0.1267 \\
INFR & 0.2125 & 0.1891 & 0.1693 & 0.1616 & 0.3156 & 0.2990 & 0.2076 & 0.1628 \\
LT & 0.2055 & 0.1792 & 0.1533 & 0.1354 & 0.3049 & 0.2536 & 0.1425 & 0.1454 \\
PRMK & 0.2154 & 0.1916 & 0.1632 & 0.1487 & 0.2472 & 0.2122 & 0.1613 & 0.1597 \\
RW & 0.1999 & 0.1710 & 0.1388 & 0.1070 & 0.3422 & 0.1800 & 0.0769 & 0.1262 \\
RPT & 0.2056 & 0.1789 & 0.1500 & 0.1232 & 0.3295 & 0.2139 & 0.1039 & 0.1405 \\
SWM & 0.1942 & 0.1656 & 0.1323 & 0.1012 & 0.3258 & 0.1845 & 0.0781 & 0.1208 \\
SW & 0.2007 & 0.1717 & 0.1382 & 0.1097 & 0.3381 & 0.1732 & 0.0752 & 0.1324 \\
KC & 0.2004 & 0.1723 & 0.1404 & 0.1139 & 0.2844 & 0.2192 & 0.1151 & 0.1301 \\
\hline NOE
\end{tabular}

Note: $\mathrm{BA}=$ water bodies, $\mathrm{SMK}=$ shrub, $\mathrm{HT}=$ nature forest, $\mathrm{KR}=$ Rubber, INFR=Building, $\mathrm{LT}=\mathrm{open}$ land or waste land, $\mathrm{PRMK}=$ settlement, $\mathrm{RW}=$ swamp, $\mathrm{RPT}=$ grassland, $\mathrm{SWM}=$ young oil palm, $\mathrm{SW}=$ oil palm, $\mathrm{KC}=$ mix agriculture (cassava plantation)

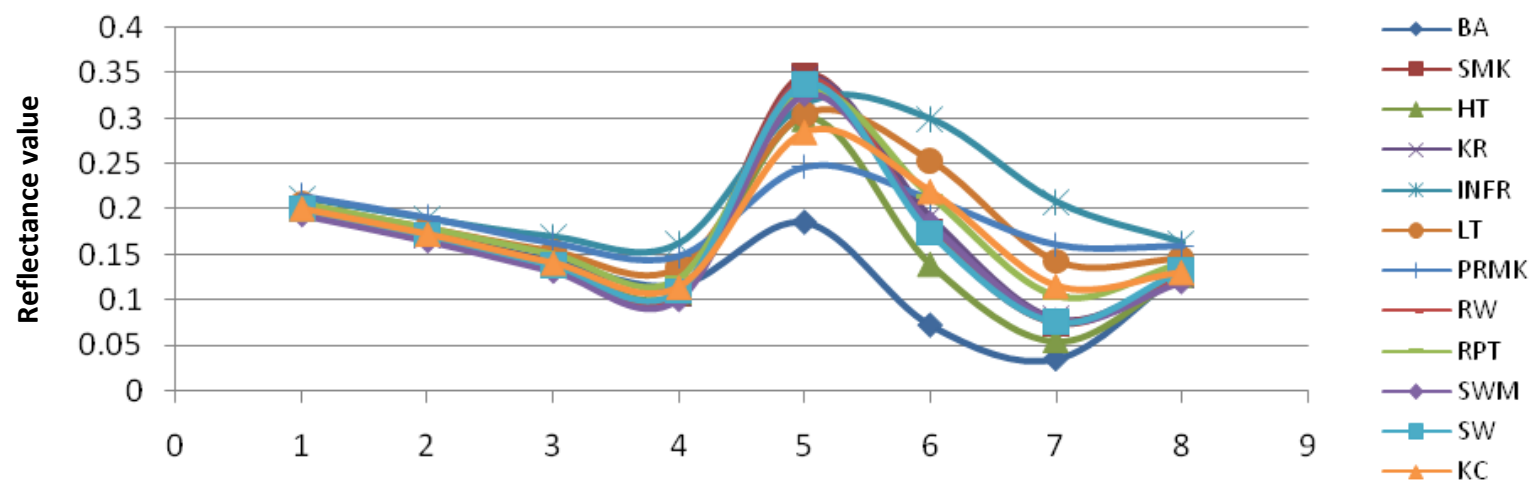

Figure 1. Reflectance values of color spectrum analysis B1-8 on 12 types of land cover in Balai Raja and Tesso Nilo, Riau, Indonesia 
Table 2. The coefficient of kappa in comparison between the reflectance values of the actual land cover condition through a series of checks in the field

\begin{tabular}{|c|c|c|c|c|c|c|c|c|c|c|c|c|}
\hline & $\mathbf{B A}$ & SMK & HT & KR & INFR & LT & PRMK & RW & RPT & SWM & SW & $\mathrm{KC}$ \\
\hline BA & $18 \mathrm{a}$ & 0 & 0 & 0 & 0 & 0 & 0 & 0 & 0 & 0 & 0 & 0 \\
\hline SMK & 0 & 3 & 0 & 1 & 0 & 0 & 0 & 3 & 0 & 0 & 0 & 0 \\
\hline HT & 0 & 0 & 10 & 0 & 0 & 0 & 0 & 2 & 0 & 0 & 1 & 0 \\
\hline $\mathrm{KR}$ & 0 & 0 & 0 & 9 & 0 & 0 & 0 & 0 & 0 & 0 & 0 & 0 \\
\hline INFR & 0 & 0 & 0 & 0 & 10 & 1 & 0 & 0 & 0 & 0 & 0 & 0 \\
\hline $\mathrm{LT}$ & 0 & 0 & 0 & 0 & 2 & 9 & 0 & 0 & 0 & 0 & 0 & 0 \\
\hline PRMK & 0 & 0 & 0 & 0 & 1 & 0 & 6 & 0 & 0 & 0 & 0 & 0 \\
\hline RW & 0 & 0 & 0 & 0 & 0 & 0 & 0 & 3 & 0 & 0 & 0 & 0 \\
\hline RPT & 0 & 0 & 0 & 2 & 2 & 1 & 0 & 0 & 3 & 0 & 1 & 0 \\
\hline SWM & 0 & 0 & 0 & 0 & 0 & 0 & 0 & 0 & 0 & 1 & 0 & 0 \\
\hline SW & 0 & 0 & 1 & 1 & 0 & 0 & 0 & 1 & 0 & 0 & 3 & 0 \\
\hline $\mathrm{KC}$ & 0 & 0 & 0 & 0 & 0 & 0 & 0 & 0 & 0 & 0 & 0 & 4 \\
\hline
\end{tabular}

Note: $\mathrm{a}=$ the number of land cover check points, $\mathrm{BA}=$ water bodies, $\mathrm{SMK}=$ shrub, $\mathrm{HT}=$ nature forest, KR=Rubber, INFR=Building, $\mathrm{LT}=$ open land or waste land, $\mathrm{PRMK}=$ settlement, $\mathrm{RW}=$ swamp, RPT=grassland, SWM=young oil palm, SW=oil palm, KC=mix agriculture (cassava plantation)

\section{Land cover in color spectral analysis}

Landsat 8 OLI + and involving band 1-8 were used in this study. From the results of spectral use (Erdass Software) to identify land cover, 12 land covers could be identified in Balai Raja and Tesso Nilo. The land covers were water bodies, natural forest, rubber plantation, open land or waste land, grassland, young oil palm, and old palm oil plantation, acacias, bushes, settlements, and mixed agriculture.

Of the total extent available in Balai Raja, oil palm plantation and mixed agriculture had the largest area in the Desma habitat, while the water body had the smallest area. Then from the total area of the Tesso Nilo, acacia plantation has the largest as the habitat of Angelina and Butet, then the forest with the second largest place within the habitat of both groups of elephants. The third largest place was placed by the oil palm area, and the water body had the smallest area.

\section{$\mathbf{5 0 \%}$ and $95 \%$ kernel density analysis}

Kernel density analysis is often used in habitat use study or determining locations where concentrations of animal movements occurred (Getz and Wilmers 2004; Francesca et al. 2010; Sitompul 2011). The kernel density could answer and identified the locations where the elephants were most intensively visited. This study took in $50 \%$ and $95 \%$ of fix kernel so that it could be known in a more certain level about habitat elephant election. Then in the kernel density, the character of the land cover was identified and inferred from the percentage of area used by each elephant group.

In the habitat selection with kernel density, the position and extent of land cover were identified based on total elephant activity times i.e., morning, noon, and night, especially for Desma and Angelina. From the results of kernel density analysis in MCP of Desma, Angelina, and Butet, the distribution of Desma concentrations was scattered in several locations within the habitat space. One separate location was to the south of the area. For Angelina, the concentration of movement is only in one location from the kernel density analysis, whereas for Butet, the choice of location for the activity was in the north of its habitat space, although it also spread to the south.

For the concentration of movement in the morning, day, and night, Desma looked still in the same position although there was little movement. It was also the same experienced with Angelina where shifts in the morning, day, and night were in the same location. To see the spatial interpretation of the concentration of Desma's distributions more clearly, Figure 3 explained its concentration movements in all of the groups including activity time.

From the identification of land covers (based on spectral coloring analysis of Landsat 8 OLI+) in the 50\% kernel for Desma activity conditions in the morning, the day, and the evening were almost the same in habitat selection based on land cover type's identification. In the morning activities, the area of habitat used by Desma was more dominant for mixed agriculture (cassava areas), forests, and shrubs, while in the daytime was relatively the same in mixed agriculture, forests, and shrubs, but the area in mixed agriculture was increased than the forest. Then at night, the activities began to increase in the area of oil palm, rubber plantation, and grass areas although mixed agriculture and forests were still dominant. In general (\% relative total), Desma selected mixed agriculture and forests as the habitat areas in their daily activities. Oil palm plantation, rubber plantation, shrubs, and open land including waste land were other locations visited by Desma. 

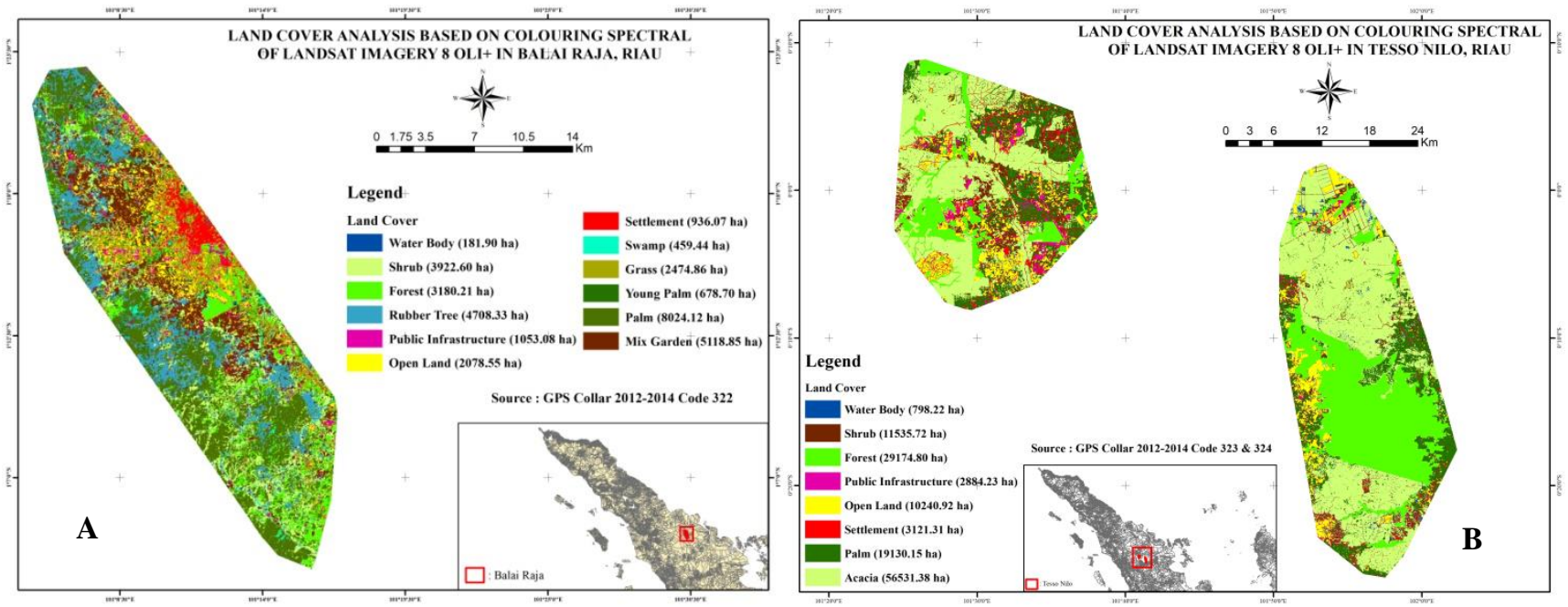

Figure 2. Spatial distribution of land covers in Desma, Angelina and Butet's MCP at Balai Raja (A) and Tesso Nilo (B), Riau, Indonesia
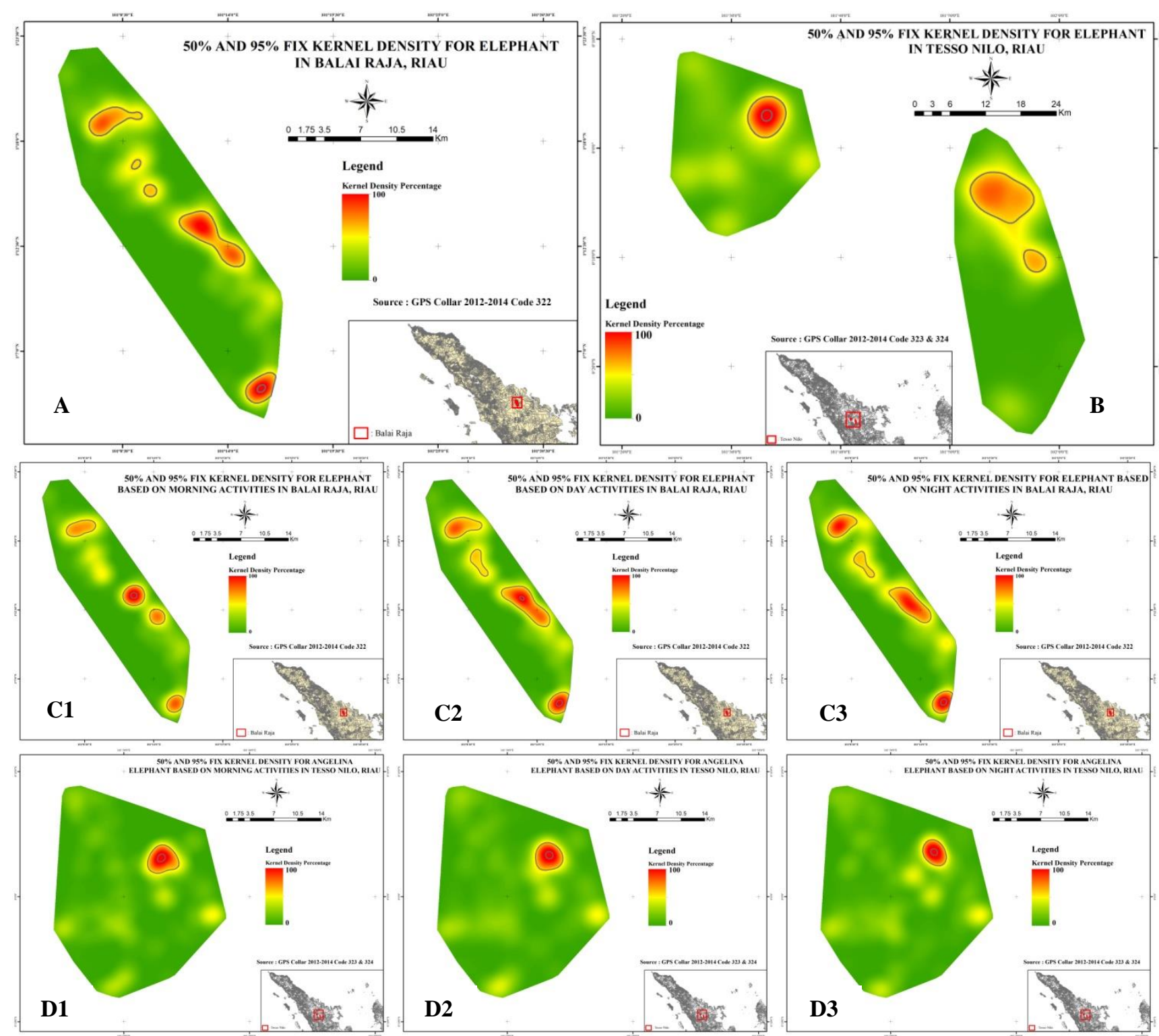

Figure 3. $50 \%$ kernel density and $95 \%$ Desma movements (A), Angelina and Butet (B) and kernel density of Desma (C1-3) and Angelina (D1-3) based on morning, day, and night activities 
Table 3. Kernel density range 50\% and \% relative of area at highest Desma's movement concentrations at Balai Raja, Riau, Indonesia

\begin{tabular}{|c|c|c|c|c|c|c|c|c|}
\hline $\begin{array}{c}\text { Balai } \\
\text { Raja's } \\
\text { variable }\end{array}$ & $\begin{array}{c}\text { K- } \\
\text { morning } \\
\left(\mathrm{km}^{2}\right)\end{array}$ & $\begin{array}{c}\% \mathrm{~K}- \\
\text { morning }\end{array}$ & $\begin{array}{c}\text { K-day }{ }^{\mathrm{a}} \\
\left(\mathbf{k m}^{2}\right)\end{array}$ & $\begin{array}{l}\text { \% relatif } \\
\text { K-day }\end{array}$ & $\begin{array}{c}\text { K-night } \\
\left(\mathbf{k m}^{2}\right)\end{array}$ & $\%$ K-night & $\begin{array}{c}\text { K-total } \\
\text { Desma } \\
\left(\mathrm{km}^{2}\right) \\
\end{array}$ & $\%$ K-total \\
\hline BA & 0.16 & 0.67 & 0.37 & 0.89 & 0.27 & 0.72 & 0.18 & 0.64 \\
\hline SMK & 2.45 & 10.29 & 4.30 & 10.19 & 3.94 & 10.48 & 2.77 & 9.81 \\
\hline HT & 5.76 & 24.23 & 7.59 & 18.00 & 6.93 & 18.46 & 6.04 & 21.39 \\
\hline KR & 2.17 & 9.13 & 4.02 & 9.54 & 4.04 & 10.77 & 2.69 & 9.53 \\
\hline INFR & 0.81 & 3.38 & 1.42 & 3.37 & 1.34 & 3.57 & 0.97 & 3.44 \\
\hline LT & 2.00 & 8.42 & 3.87 & 9.17 & 3.22 & 8.56 & 2.22 & 7.87 \\
\hline PRMK & 0.08 & 0.33 & 0.14 & 0.33 & 0.12 & 0.33 & 0.07 & 0.27 \\
\hline RW & 0.47 & 1.98 & 0.85 & 2.02 & 0.72 & 1.92 & 0.62 & 2.19 \\
\hline RPT & 1.04 & 4.37 & 2.49 & 5.91 & 2.31 & 6.15 & 1.34 & 4.76 \\
\hline SWM & 0.20 & 0.85 & 0.53 & 1.26 & 0.58 & 1.55 & 0.35 & 1.24 \\
\hline SW & 1.93 & 8.10 & 3.84 & 9.12 & 3.77 & 10.05 & 2.68 & 9.49 \\
\hline \multirow[t]{2}{*}{$\mathrm{KC}$} & 6.72 & 28.24 & 12.72 & 30.19 & 10.30 & 27.44 & 8.29 & 29.37 \\
\hline & 23.79 & 100 & 42.14 & 100 & 37.54 & 100 & 28.23 & 100 \\
\hline
\end{tabular}

Table 4. Kernel density range $50 \%$ and $\%$ relative of area at highest Angelina's movement concentrations at Tesso Nilo, Riau, Indonesia

\begin{tabular}{|c|c|c|c|c|c|c|c|c|c|c|c|c|}
\hline $\begin{array}{c}\text { Variabel } \\
\text { Tesso Nilo }\end{array}$ & $\begin{array}{c}\text { K- } \\
\text { morning } \\
\left(\mathbf{k m}^{2}\right)\end{array}$ & $\begin{array}{c}\% \mathrm{~K}- \\
\text { morning }\end{array}$ & $\begin{array}{c}\text { K-day }^{\mathbf{b}} \\
\left(\mathbf{k m}^{2}\right)\end{array}$ & $\begin{array}{l}\% \text { K- } \\
\text { day }\end{array}$ & $\begin{array}{c}\text { K- } \\
\text { nightb }^{b} \\
\left(\mathbf{k m}^{2}\right)\end{array}$ & $\begin{array}{l}\% \mathrm{~K}- \\
\text { night }\end{array}$ & $\begin{array}{c}\text { K-total } \\
\text { Angln } \\
\left(\mathbf{k m}^{2}\right)\end{array}$ & $\begin{array}{c}\% \\
\text { Angln } \\
\text { K-total }\end{array}$ & $\begin{array}{c}\text { K- } \\
\text { Butet } \\
\left(\mathbf{k m}^{2}\right)\end{array}$ & $\begin{array}{l}\% \text { K- } \\
\text { Butet }\end{array}$ & $\begin{array}{c}\text { K-Tesso Nilo } \\
\text { (inc. Angelina } \\
\text { \& Butet) } \\
\left(\mathbf{k m}^{\mathbf{2}}\right)\end{array}$ & $\begin{array}{l}\% \mathrm{~K}- \\
\text { Tesso } \\
\text { Nilo }\end{array}$ \\
\hline BA & 0.002 & 0.02 & 0.004 & 0.04 & 0.0009 & 0.01 & 0.002 & 0.02 & 0.14 & 0.89 & 0.75 & 0.68 \\
\hline SMK & 1.44 & 11.05 & 1.40 & 13.87 & 1.39 & 9.66 & 1.15 & 11.89 & 0.39 & 2.40 & 7.36 & 6.74 \\
\hline HT & 0.00 & 0.00 & 0.00 & 0.00 & 0.00 & 0.00 & 0.13 & 1.37 & 0.34 & 2.11 & 2.38 & 2.18 \\
\hline INFR & 1.20 & 9.19 & 0.87 & 8.62 & 1.21 & 8.44 & 0.85 & 8.77 & 0.03 & 0.20 & 2.55 & 2.33 \\
\hline $\mathrm{LT}$ & 0.30 & 2.30 & 0.19 & 1.85 & 0.52 & 3.65 & 0.28 & 2.92 & 0.21 & 1.28 & 2.71 & 2.48 \\
\hline PRMK & 0.53 & 4.09 & 0.31 & 3.03 & 0.70 & 4.89 & 0.36 & 3.77 & 0.03 & 0.19 & 2.14 & 1.96 \\
\hline SW & 1.92 & 14.71 & 2.41 & 23.87 & 1.56 & 10.87 & 1.65 & 17.08 & 3.65 & 22.46 & 11.74 & 10.76 \\
\hline Akasia & 7.64 & 58.65 & 4.92 & 48.72 & 8.98 & 62.50 & 5.23 & 54.17 & 11.45 & 70.48 & 79.50 & 72.86 \\
\hline TOTAL & 13.03 & 100 & 10.11 & 100 & 14.37 & 100 & 9.66 & 100 & 16.22 & 100.00 & 109.12 & 100.00 \\
\hline
\end{tabular}

Note: $\mathrm{a}=$ Desma, $\mathrm{b}=$ Angelina, Angln $=$ Angelina, $\mathrm{K}=\geq 50 \%$ fix Kernel density

For Angelina and Butet, the acacia plantation was the dominant area for their intensive activities (54.2 and70.5\% $(72.9 \%))$. The choice of acacia habitat in both Angelina and Butet was because this location is relatively safe compared to other locations. Although the coverage area of oil palm plantation $(10.76 \%)$ and shrub $(6.74 \%)$ was also high as the activity sites by Angelina and Butet this location might not be favored because of the high conflict with humans. In this context, Angelina and Butet did not provide a lot of other land covers such as forests and open land. Interestingly, the water bodies, which is a pool of water, is not found in Angelina's intensively roaming space but is recorded in the Butet area, but the river is relatively sufficiently recorded but not intensively used. For the daily activity of Angelina on the morning, day, and night still tended to use acacia cover. The percentage of acacia use during the day decreased compared to morning and night. On the day, Angelina increased activities to use the oil palm chamber as the location for her activity. In the location where the highest concentration of movement, Angelina did not use the forest space at all. It differed with Butet that still used forest cover for her activity (about 2\% of all forest cover in the $50 \%$ kernel density).

\section{Habitat preference index}

The habitat preference index is used to see in detail of the elephant habitat selection based on the frequency of elephant arrival to these habitat types as compared to the habitat extent within the $50 \%$ fix kernel. The elephant arrival frequency is the number of elephant arrivals detected from the GPS Collar in one type of habitat. The habitat area within the $50 \%$ fix kernel had been identified in 12 habitat types in the Desma region and eight habitat types in the region of Angelina and Butet. In the context of the habitat preference index, the frequency of elephants arrival in the morning, afternoon, and the evening was identified primarily for Desma and Angelina.

At the frequency of elephant arrivals in the $50 \%$ Kernel fix, Desma was more likely to visit natural forest (187; $271 ; 191$ arrivals with the proportion $0.37 ; 0.4 ; 0.3$ ) and mixed gardens $(153 ; 201 ; 198$ times arrivals with a proportion of $0.3 ; 0.29 ; 0.31)$ in the morning, noon, and night or the whole time. Total of Desma's visited the natural forest and the mixed gardens were 264 (proportions 0.36 ) and 205 times (proportion 0.28) arrivals. In the context of the proportion of Desma in the $50 \%$ fix kernel, the proportion of natural forest and the mixed garden was 
highest compared to other habitat types, including in the morning, day, and night Desma activity (see Table 6).

From Jacob's index, the most dominant habitat selection by Desma was the natural forest (IPH 0.35) and more natural forest habitat selection during the day (IPH 0.5), morning (IPH 0.29) and night (IPH 0.11) (see Table 6). Then, the second dominant habitat selection was swamp (IPH 0.18) where the highest swamp selection by Desma was during the day (IPH 0.23). Although mixed gardens have the highest extent in the 50\% kernel fix and Desma's visit to this site is relatively high, but in the selection of habitat at the site is low (IPH 0.04) or less used at night. From Jacob's index, Desma avoided settlements, open land and does not seem to use much water bodies and grass areas. Desma also seems positive to the palm though as a location of movement or used as shade during the day. Young Palm was identified in the 50\% fix kernel, but in the implementation of the Desma movement, Desma did not use this location because of the high risk of conflict with humans.

In the location of Angelina and Butet, the highest arrival frequency was in acacia plantation (the frequency of arrival of Angelina was 143 times (proportion 0.67) and Butet was 210 times (proportion 0.70)). Then the relatively high arrival frequency was to the location of the old oil palm plantation (Angelina with 36 times of arrival (proportion 0.17) and Butet with 54 times of arrival (proportion 0.18)). In the Butet region, natural forest was also visited relatively high at 16 times (proportion 0.05 ).

In the Jacob index, acacia as the habitat by Angelina was dominantly chosen, Angelina also approached or selected mostly open land especially in the morning (IPH 0.23). These preferences habitat were different from Butet. Butet preferred public buildings or public infrastructure (IPH 0.80), natural forests (IPH 0.45) and open land (0.35) as selected habitats. Acacia though the number of arrivals was high due to wide proportions, habitat preference was low (IPH-0.02). Angelina avoided bush areas, infrastructure, and settlements. Water bodies at Angelina's site were identified as very small and not visited by Angelina. Butet avoided settlement and used of water bodies was relatively small. While Angelina used palm habitat for night activities (IPH 0.21).

Table 5. Frequencies of the elephant arrival (Desma) and 50\% fix Kernel at Balai Raja, Riau, Indonesia in the morning, the day, and the night

\begin{tabular}{|c|c|c|c|c|c|c|c|c|}
\hline $\begin{array}{c}\text { Balai Raja's } \\
\text { variables }\end{array}$ & F-morning & $\begin{array}{c}\text { K-morning } \\
\left(\mathbf{k m}^{2}\right)\end{array}$ & F-day & $\begin{array}{c}\text { K-day } \\
\left(\mathbf{k m}^{2}\right)\end{array}$ & F-night & $\begin{array}{c}\text { K-night } \\
\left(\mathbf{k m}^{2}\right)\end{array}$ & F-Desma & $\begin{array}{c}\text { K-Desma } \\
\left(\mathbf{K m}^{2}\right)\end{array}$ \\
\hline $\mathrm{BA}$ & 0 & 0.16 & 2 & 0.37 & 0 & 0.27 & 1 & 0.18 \\
\hline SMK & 47 & 2.45 & 38 & 4.3 & 54 & 3.94 & 59 & 2.77 \\
\hline HT & 187 & 5.76 & 271 & 7.59 & 191 & 6.93 & 264 & 6.04 \\
\hline KR & 44 & 2.17 & 49 & 4.02 & 52 & 4.04 & 54 & 2.69 \\
\hline INFR & 8 & 0.81 & 12 & 1.42 & 16 & 1.34 & 14 & 0.97 \\
\hline $\mathrm{LT}$ & 6 & 2 & 17 & 3.87 & 18 & 3.22 & 20 & 2.22 \\
\hline PRMK & 0 & 0.08 & 0 & 0.14 & 1 & 0.12 & 0 & 0.07 \\
\hline RW & 12 & 0.47 & 22 & 0.85 & 21 & 0.72 & 23 & 0.62 \\
\hline RPT & 11 & 1.04 & 8 & 2.49 & 10 & 2.31 & 13 & 1.34 \\
\hline SWM & 0 & 0.2 & 0 & 0.53 & 0 & 0.58 & 0 & 0.35 \\
\hline SW & 43 & 1.93 & 66 & 3.84 & 75 & 3.77 & 75 & 2.68 \\
\hline $\mathrm{KC}$ & 153 & 6.72 & 201 & 12.72 & 198 & 10.3 & 205 & 8.29 \\
\hline Total & 511 & 23.79 & 686 & 42.14 & 636 & 27.24 & 728 & 28.22 \\
\hline
\end{tabular}

Note: $\mathrm{F}=$ Frequences, $\mathrm{K}=$ Kernel

Table 6. Jacob's preference index on the proportion of frequencies of the elephant arrival (Desma) and land area in 50\% fix Kernel at Balai Raja, Riau, Indonesia (including in the morning, the day, and the night)

\begin{tabular}{lccccccccccccc}
\hline $\begin{array}{c}\text { Balai } \\
\text { Raja's } \\
\text { variables }\end{array}$ & $\begin{array}{c}\text { PF- } \\
\text { mrng }\end{array}$ & $\begin{array}{c}\text { PK- } \\
\text { mrng }\end{array}$ & $\begin{array}{c}\text { PF- } \\
\text { day }\end{array}$ & $\begin{array}{c}\text { PK- } \\
\text { day }\end{array}$ & $\begin{array}{c}\text { PF- } \\
\text { night }\end{array}$ & $\begin{array}{c}\text { PK- } \\
\text { night }\end{array}$ & $\begin{array}{c}\text { PF- } \\
\text { Desma }\end{array}$ & $\begin{array}{c}\text { PK- } \\
\text { Desma }\end{array}$ & & $\begin{array}{c}\text { IPH } \\
\text { Mrng }\end{array}$ & $\begin{array}{c}\text { IPH } \\
\text { Day }\end{array}$ & $\begin{array}{c}\text { IPH } \\
\text { Night }\end{array}$ & $\begin{array}{c}\text { IPH } \\
\text { Desma }\end{array}$ \\
\hline BA & 0.00 & 0.01 & 0.00 & 0.01 & 0.00 & 0.01 & 0.00 & 0.01 & & -1.00 & -0.50 & -1.00 & -0.65 \\
SMK & 0.09 & 0.10 & 0.06 & 0.10 & 0.08 & 0.14 & 0.08 & 0.10 & & -0.06 & -0.32 & -0.29 & -0.10 \\
HT & 0.37 & 0.24 & 0.40 & 0.18 & 0.30 & 0.25 & 0.36 & 0.21 & & 0.29 & 0.50 & 0.11 & 0.35 \\
KR & 0.09 & 0.09 & 0.07 & 0.10 & 0.08 & 0.15 & 0.07 & 0.10 & & -0.03 & -0.16 & -0.32 & -0.14 \\
INFR & 0.02 & 0.03 & 0.02 & 0.03 & 0.03 & 0.05 & 0.02 & 0.03 & & -0.38 & -0.32 & -0.33 & -0.29 \\
LT & 0.01 & 0.08 & 0.02 & 0.09 & 0.03 & 0.12 & 0.03 & 0.08 & & -0.77 & -0.60 & -0.64 & -0.50 \\
PRMK & 0.00 & 0.00 & 0.00 & 0.00 & 0.00 & 0.00 & 0.00 & 0.00 & & -1.00 & -1.00 & -0.48 & -1.00 \\
RW & 0.02 & 0.02 & 0.03 & 0.02 & 0.03 & 0.03 & 0.03 & 0.02 & & 0.09 & 0.23 & 0.11 & 0.18 \\
RPT & 0.02 & 0.04 & 0.01 & 0.06 & 0.02 & 0.08 & 0.02 & 0.05 & & -0.35 & -0.68 & -0.71 & -0.47 \\
SWM & 0.00 & 0.01 & 0.00 & 0.01 & 0.00 & 0.02 & 0.00 & 0.01 & & -1.00 & -1.00 & -1.00 & -1.00 \\
SW & 0.08 & 0.08 & 0.10 & 0.09 & 0.12 & 0.14 & 0.10 & 0.09 & & 0.02 & 0.03 & -0.09 & 0.05 \\
KC & 0.30 & 0.28 & 0.29 & 0.30 & 0.31 & 0.38 & 0.28 & 0.29 & & 0.04 & -0.02 & -0.15 & -0.03 \\
Total & 1.00 & 1.00 & 1.00 & 1.00 & 1.00 & 1.00 & 1.00 & 1.00 & & & & \\
\hline
\end{tabular}

Note: $\mathrm{PF}=$ frequencies proportion, $\mathrm{PK}=$ Kernel proportion $\mathrm{IPH}=$ Jacob's habitat preference index, $\mathrm{mnrg}=$ morning 
Table 7. Frequencies of the elephant arrival (Angelina and Butet) and 50\% fix Kernel at Tesso Nilo in the morning, the day and the night condition (for Angelina)

\begin{tabular}{|c|c|c|c|c|c|c|c|c|c|c|}
\hline $\begin{array}{c}\text { Tesso Nilo's } \\
\text { variables }\end{array}$ & $\begin{array}{c}\text { F- } \\
\text { morning } \\
\text { Angl }\end{array}$ & $\begin{array}{l}\text { K-morning } \\
\left(\mathbf{k m}^{2}\right) \text { Angl }\end{array}$ & $\begin{array}{c}\text { F-day } \\
\text { Angl }\end{array}$ & $\begin{array}{c}\text { K-day } \\
\left(\mathbf{k m}^{2}\right) \\
\text { Angl }\end{array}$ & $\begin{array}{c}\text { F-night } \\
\text { Angl }\end{array}$ & $\begin{array}{c}\text { K-night } \\
\left(\mathbf{k m}^{2}\right) \\
\text { Angl }\end{array}$ & F-Angl & $\begin{array}{c}\text { K-Angl } \\
\left(\mathbf{k m}^{2}\right)\end{array}$ & F-Butet & $\begin{array}{c}\text { K-Butet } \\
\left(\mathbf{k m}^{2}\right)\end{array}$ \\
\hline $\mathrm{BA}$ & 0 & 0.002 & 0 & 0.004 & 0 & 0.001 & 0 & 0.002 & 2 & 0.14 \\
\hline SMK & 8 & 1.44 & 6 & 1.4 & 6 & 1.39 & 8 & 1.15 & 6 & 0.39 \\
\hline HT & 0 & 0 & 0 & 0 & 0 & 0 & 0 & 0.13 & 16 & 0.34 \\
\hline INFR & 8 & 1.2 & 5 & 0.87 & 9 & 1.21 & 10 & 0.85 & 5 & 0.03 \\
\hline LT & 7 & 0.3 & 3 & 0.19 & 5 & 0.52 & 6 & 0.28 & 8 & 0.21 \\
\hline PRMK & 5 & 0.53 & 2 & 0.31 & 8 & 0.7 & 9 & 0.36 & 0 & 0.03 \\
\hline SW & 24 & 1.92 & 39 & 2.41 & 32 & 1.56 & 36 & 1.65 & 54 & 3.65 \\
\hline Akasia & 141 & 7.64 & 89 & 4.92 & 144 & 8.98 & 143 & 5.23 & 210 & 11.45 \\
\hline Total absolut & 193 & 13.032 & 144 & 10.104 & 204 & 14.361 & 212 & 9.65 & 301 & 16.24 \\
\hline
\end{tabular}

Note: $\mathrm{K}=50 \%$ fix kernel, $\mathrm{F}=$ frequences, Angl=Angelina, $\mathrm{TN}=$ Tesso Nilo, IPH = Jacob's habitat preference index

Table 8. Jacob's preference index on the proportion of frequencies of the elephant arrival and land area in 50\% fix Kernel at Tesso Nilo (including in the morning, the day and the night)

\begin{tabular}{lccccccccccccccc}
\hline $\begin{array}{c}\text { Tesso Nilo's } \\
\text { variables }\end{array}$ & $\begin{array}{c}\text { PF- } \\
\text { morng }\end{array}$ & $\begin{array}{c}\text { PK- } \\
\text { morng }\end{array}$ & $\begin{array}{c}\text { PF- } \\
\text { da }\end{array}$ & $\begin{array}{c}\text { PK- } \\
\text { day }\end{array}$ & $\begin{array}{c}\text { PF- } \\
\text { night }\end{array}$ & $\begin{array}{c}\text { PK- } \\
\text { night }\end{array}$ & $\begin{array}{c}\text { PF- } \\
\text { Angelina }\end{array}$ & $\begin{array}{c}\text { PK- } \\
\text { Angelina }\end{array}$ & $\begin{array}{c}\text { PF- } \\
\text { Butet }\end{array}$ & $\begin{array}{c}\text { PK- } \\
\text { Butet }\end{array}$ & $\begin{array}{c}\text { IPH- } \\
\text { Morning } \\
\text { Angelina }\end{array}$ & $\begin{array}{c}\text { IPH-day } \\
\text { Angelina }\end{array}$ & $\begin{array}{c}\text { IPH-night } \\
\text { Angelina }\end{array}$ & $\begin{array}{c}\text { IPH-D } \\
\text { Angelina }\end{array}$ & $\begin{array}{c}\text { IPH- } \\
\text { Butet }\end{array}$ \\
\hline BA & 0.00 & 0.00 & 0.00 & 0.00 & 0.00 & 0.00 & 0.00 & 0.00 & 0.01 & 0.01 & -1.00 & -1.00 & -1.00 & -1.00 & -0.13 \\
SMK & 0.04 & 0.11 & 0.04 & 0.14 & 0.03 & 0.10 & 0.04 & 0.12 & 0.02 & 0.02 & -0.48 & -0.57 & -0.56 & -0.55 & -0.09 \\
HT & 0.00 & 0.00 & 0.00 & 0.00 & 0.00 & 0.00 & 0.00 & 0.01 & 0.05 & 0.02 & 0.00 & 0.00 & 0.00 & -1.00 & 0.45 \\
INFR & 0.04 & 0.09 & 0.03 & 0.09 & 0.04 & 0.08 & 0.05 & 0.09 & 0.02 & 0.00 & -0.40 & -0.45 & -0.33 & -0.32 & 0.80 \\
LT & 0.04 & 0.02 & 0.02 & 0.02 & 0.02 & 0.04 & 0.03 & 0.03 & 0.03 & 0.01 & 0.23 & 0.05 & -0.20 & -0.01 & 0.35 \\
PRMK & 0.03 & 0.04 & 0.01 & 0.03 & 0.04 & 0.05 & 0.04 & 0.04 & 0.00 & 0.00 & -0.23 & -0.38 & -0.11 & 0.07 & -1.00 \\
SW & 0.12 & 0.15 & 0.27 & 0.24 & 0.16 & 0.11 & 0.17 & 0.17 & 0.18 & 0.22 & -0.10 & 0.09 & 0.21 & 0.00 & -0.14 \\
Akasia & 0.73 & 0.59 & 0.62 & 0.49 & 0.71 & 0.63 & 0.67 & 0.54 & 0.70 & 0.71 & 0.31 & 0.26 & 0.18 & 0.27 & -0.02 \\
Total & $\mathbf{1 . 0 0}$ & $\mathbf{1 . 0 0}$ & $\mathbf{1 . 0 0}$ & $\mathbf{1 . 0 0}$ & $\mathbf{1 . 0 0}$ & $\mathbf{1 . 0 0}$ & $\mathbf{1 . 0 0}$ & $\mathbf{1 . 0 0}$ & $\mathbf{1 . 0 0}$ & $\mathbf{1 . 0 0}$ & & & & & \\
\hline
\end{tabular}

Note: $\mathrm{PF}=$ frequencies proportion, $\mathrm{PK}=$ kernel proportion, $\mathrm{IPH}=\mathrm{J}$ acob's habitat preference index, morng=morning

\section{Discussion}

In general, elephants can live and adapt in many habitat types. In Africa, elephant home range dominated mainly in bushland, woodland, and grassland (Okello et al. 2015). Some non-forest habitat types are also used by elephants such as in open land and agriculture lands and some live in locations with populations of human density (Lin et al. 2008, Kumar et al. 2010). In many studies, the elephant's need for water bodies is high so that in the study of habitat use, habitat preferences to habitat feasibility, water bodies including the river and dam are a strong consideration (Shannon et al. 2006; Gara 2014; Okello et al. 2015).

In the context of habitat use for elephants at Balai Raja, Desma used many oil palm plantations as a general area of movement. Then Desma also used mixed agriculture as her daily movement. However, in the habitat preference, Desma seemed to prefer natural forests and swamps as a more intensive choice than other habitat types. The selection of natural forests and swamps seemed appropriate for Desma because both locations were relatively safe, and human activity was lacking. Swamps are also a habitat for elephants where many locations have puddles that are useful for the elephant need (Kumar et al. 2010; Puyravaud et al., 2016). Natural forests and swamps were more likely to be used by Desma during the day for shade from the sun and getting lower body temperature or took water for elephant needs.
Desma also selected oil palm plantation in low level especially during the day for shade. Elephant movements in oil palm plantations are generally at risk and have implications for the conflict. From directly research records or based on the information of the intensive patrol team, the locations of the Desma movement were disrupted by several community groups when entering the oil palm plantations. In fact, old palm plantations are quite safe against elephant attacks, but within the area, companies or communities also have relatively more keep young oil palms from pigs and elephants. The use of the plantation is only a pathway, forced to do and not for a lot of day-to-day activities.

From the arrival frequency, Desma often visited the mixed agriculture even though the preference index was low. The pattern of relationship between cassava farmers and elephants was neutral or not mutual competition and synergy. The use of habitat in mixed agriculture of cassava and other intercropping plants was relatively safe. It meant that in certain intensity, elephants were relatively safe to use this location, although the movement of elephants was also observed by this cassava farmer (Sukmantoro and Agusrin 2017). From the results of discussions and education to the farmers of cassava farmers, they seemed to be preparing for the elephant arrival, and by 2014, at least three to four towers of view were built and assisted by the 
design and research of elephant patrol team from the local community.

In Tesso Nilo, acacia plantation was intensively used by elephants. It could be seen from the extent of the use of acacia habitats by Angelina and Butet and from the frequency of arrival of both elephants. Acacia habitat selection is also the most dominant area, especially for Angelina, but for Butet, acacia, as well as land that is used intensively, Butet's arrival reaches 210 times, but it is not concentrated in a narrow area so that concentration is not as dense as infrastructure, forests and open land. Previously researches reported that acacia plantation is indeed as a potent habitat for elephants because it is relatively safe from human disturbance. The company concession also had stages in the management and avoidance of elephants and more importantly, there is no negative association between elephants and acacia concerning disruption to acacia plants and the concession workers. Although many outside of Riau, elephants acted as an intruder (Botha 2002; Gandiwa et al. 2011). In previous records for land use in Tesso Nilo, acacia was used as dominant by elephants as a habitat of $33.74 \%$. Then the young secondary forest occupied the second dominance (Sukmantoro et al. 2013).

The habitat selection of open land was interesting. The open land became a strong choice for Butet and Angelina in the morning because of the chances of getting food and safe from human interference. In the strategy of conflict reduction and management of elephant habitat of Balai Raja, the use of open land including wasteland was the most potentially recommended for elephant habitat (later in strategy and land suitability analysis). This identification had been made in previous researches (Desai and Samsuardi 2009; Sukmantoro et al. 2014).

For Butet, the selection of factories or offices of acacia concessions as part of their habitat was interesting because the location was relatively safe from human and acacia workers did not seem to disturb the elephant. The arrival of Butet and his group near the infrastructure was often described by concession workers at the site. The condition of the natural forest in Balai Raja had been identified more broadly based on reflectance value. The forest area at Balai Raja may also be mix with agroforestry type within the MCP of Balai Raja. In many places, people still have the agro-forest area that are fruits combined with rubber or with other intercrops in the forest system. For the forest area in Tesso Nilo is factual because the remaining forest estates of the national park and the remaining forest as HCVF (High Conservation Value Forest) within the company's acacia concession express the extent corresponding to the spectral outcome.

\section{Conclusion}

From the case of the habitat use of elephants at Balai Raja and Tesso Nilo, oil palm plantations and mixed agriculture had the dominant extent that elephants use in their activities. But in habitat preference, Desma preferred natural forest and swamp, Angelina preferred acacia plantation and open land, while Butet preferred infrastructure, natural forest, and open land. The relationship between oil palm plantations and elephants was a negative relationship or included as a risky relationship because of high conflict potential with human and this was proven with the results in the field that elephant and human conflict happened in this location. In Balai Raja, the position of elephants concentration was separated in the north and south (see Figure 3), and between these locations were the area of oil palm and rubber plantations, and conflicts occured along this path. The potential use of forest remnants in Balai Raja by elephants is relatively high and elephants had chosen these areas.So decent forest governance for the Desma's group is one of the strongest strategies for managing elephant populations and decreasing conflicts, one of which will be to improve habitat quality or forest carrying capacity for elephants and entry to an ideal habitat area or suitable area.

The mixed agriculture was a neutral location, but this area did not use as a viable habitat because foods or the needs for elephants were relatively zero percent unless there wass a water body in that area. Foods for elephants were relatively non-existent in this region due to intensive farming patterns of rubber cassava (shrubs and other vegetation removed). This is similar to the Eucalyptus type for HTI (Industrial Plantation Forest). Eucalyptus as a substitute plant of acacia became the favorite plant of the concession company because of its relatively rapid growth and rarely branching, but the land under it is empty or empty of vegetation interrupted. So that the food for the elephant is relatively zero as well, in contrast to the acacia where there are still plants around this acacia for the need for elephants.

In Tesso Nilo, acacia concessions are the dominant habitats used by elephants. These areas are relatively safe and have relatively moderate diversity for undocumented sites. In some places of acacia plantation in Tesso Nilo from the Tohir (2018) study, acacia which returned succession became forest (not harvested for a long time), species richness $>5.0$ (richness index value for seedling to old trees was 5.05-12.07) or high value and biodiversity index 2.8-> 3.0 or biodiversity value is medium-high (biodiversity index value of seedlings to old trees is 2.81 3.78) (Tohir 2018).

For optimization strategies, elephants and humans do not fight for the resources (interspesific competition) (Gerhardt et al. 2014), so habitat selection for elephants is selective by reducing infrastructure and settlement areas as locations visited. The use of the location of human activities raises elephant-human conflict. Therefore, elephant habitat locations need to be intensified in habitat development programs by increasing habitat support capacity for elephants and intensifying habitat development also in potential locations that were not selected by elephants such as water bodies, mixed gardens, open land and bushes.

For humans, knowledge of elephant roaming is important, especially knowing the strategy of sharing habitat with the elephants, so that humans reduce activities in this region. Human roaming areas are certainly higher than elephants, spatial planning for humans becomes important for the purpose of reducing threats and conflicts against the elephants. In this context, humans better adapt 
and understand the appropriate habitats, and elected elephants and humans can avoid these areas or build a optimize that is mature so that the conflict and interceptive competitions between them are down even nonexistent.

\section{ACKNOWLEDGEMENTS}

We express our gratitude to the Ministry of Environment and Forestry-Indonesian Republic, WWF US, AREAS, WWF Indonesia, and Bogor Agriculture Institute which gave supported in many aspects related to this research. We also thank Fadlan Pramatana (GIS expert), all of field team member, especially the GPS Collar installation team and the WWF elephant patrol team, the Tesso Nilo Foundation, the Tesso Nilo National Park Authority, BKSDA Riau section III and colleagues who individually assisted in the research.

\section{REFERENCES}

Ardiansyah. 2015. Remote sensing image processing using ENVI 5.1 and ENVI Lidar (theory and practice)Satellite imagery Laboratory, Jakarta, Indonesia. [Indonesian]

Azmi W, Gunaryadi D. 2011. Current status of Asian elephants in Indonesia. Gajah 35: 55-61.

Beyer HL, Haydon DT, Morales JM, Frair JL, Hebblewhite, Mitchell MM, Matthiopoulos J. 2010. The interpretation of habitat preference metrics under use-availability designs. Philos Trans R Soc Lond B Biol Sci. 365 (1550) : 2245-2254

Blouch RA, Simbolon K.1985. Elephants in North Sumatra. IUCN-WWF Report No. 9, Project 303, Bogor. [Indonesian]

Botha J, Witkowski ETF, Shackleton CM. 2002. A comparison of anthropogenic and elephant disturbance on Acacia xanthophloea (fever tree) populations in the Lowveld, South Africa. Koedoe 45 (1) $9-18$.

de Souza CHW, Mercante E., Prudente VHR, Justina DDD. 2013 Methods of performance evaluation for the supervised classification of satellite imagery in determining land cover classes. Cien Inv Agr 40 (2): 419-428.

Desai AA, Riddle HS. 2015. Human elephant conflict in Asia. US Fish and Wildlife Service report.

Desai AA, Syamsuardi. 2009. Elephant status in Riau Province, Indonesia. WWF Indonesia technical report, Riau [Indonesian].

Francesca C., Boitani L, Roger Powell RA, Boyce MS. 2010. Animal ecology meets GPS-based radiotelemetry: a perfect storm of opportunities and challenges. Philos Trans R Soc Lond B Biol Sci. 365: 2157-2162.

Gandiwa T, Magwati T, Zisadza P, Chinuwo T, Tafangenyash C. 2011 The impact of African elephants on Acacia tortilis woodland in northern Gonarezhou National Park, Zimbabwe. J Arid Environ. 75 (9): 809-814

Gara TW. 2014. Effect of water availability, landscape fragmentation and forage abundance on the movement and habitat utilizations of elephant. Faculty of Geo-information science and earth observation. Netherland (NLD): University of Twente.
Gerhardt KV, van Niekerk A, Kidd M, Samways M, Hanks J. 2014. The role of elephant Loxodonta africana pathways as a spatial variable in crop-raiding location. Oryx: 1-9.

Getz WM, Wilmers CC. 2004. A local nearest-neighbor convex-hull construction of home ranges and utilization distributions. Ecography 27: 485-505.

Kumar MA, Mudappa D, Raman RS. Asian elephant Elephas maximus habitat use and ranging in fragmented rainforest and plantations in the Anamalai Hills, India. Trop Conserv Sci.3 (2): 143-158.

Lin L, Feng L, Pan W, Guo X, Zhao J, L Aidong, Zhang L. 2008. Habitat selection and the change in distribution of Asian elephants in Mengyang Protected Area, Yunnan, China. Acta Theriol.53 (4): 365 374

Mishra SR, Sethy J, Bisht HK. 2015. Study on human-elephant conflict in Baripada Division of, Mayurbhanja, Odisha, India J Wildl Res 3 (3): 21-26.

Okello MM, Njumbi SJ, Kiringe JW, Isiiche J. 2015. Habitat use and preference by the African elephant outside of the protected area, and management implications in the Amboseli Landscape, Kenya. Int $\mathbf{J}$ BiodiversConserv 7: 211-236.

Puyravaud JP, Cushman SA, Davidar P, Madappa D. 2016. Predicting landscape connectivity for the Asian elephant in its largest remaining subpopulation. Anim Conserv.1-10.

Rahman MM, Csaplovics, Koch EB, Köhl M. 2004. Interpretation of tropical vegetation using landsat 7 ETM+ imagery. Bangladesh Space Research and Remote Sensing Organization (SPARRSO).

Senthilkumar K, Mathialagan P, Manivannan C, Gomathinayagam S. 2016. Human-elephant conflict: case study from Tamil Nadu. Int J Sci Environ Technol 5 (6): 445-448.

Shannon G, Page B, Slotow R, Duffy K. 2006. African elephant home range and habitat selection in Pongola Game Reserve, South Africa. Afr Zool 41 (1): 37-44.

Sitompul AF, Griffin CF, Fuller TK. 2013. Sumatran elephant ranging behavior in a fragmented rainforest landscape. Int $\mathrm{J}$ Biodivers Conserv.5 (2): 66-72

Sitompul AF. 2011. Ecology and Conservation of Sumatran Elephants (Elephas maximus sumatranus) in Sumatra, Indonesia Doctor of Philosophy (February 2011), Environmental Conservation. University of Massachusetts-Amherst.

Suhartono T, Susilo HD, Sitompul AF, Gunaryadi D, Purastuti EM, Azmi W, Fadhli N, Stremme C. 2008. 2007 - 2017 Conservation strategy and action plan of the Sumatran Elephant and Bornean Pygmy Elephant. Ministry of forestry - Indonesia Republic, Jakarta. [Indonesian]

Sukmantoro W, Purastuti E, Samsuardi, Sudibyo A, Fadli N. 2013. Installation and study on the use of GPS Collar on Sumatran Elephant Elephas maximus sumatranus in Tesso Nilo National Park, Riau Province (2007-2009). WWF Indonesia-AREAS report, Riau. [Indonesia]

Sukmantoro W, Sudibyo A, Hutomo M, Samsuardi. 2014. Elephant habitat improvement through satellite image Landsat 7 ETM+ analysis in Balai Raja, Riau Province. Proceeding Asian Elephant Symposium at the Society for Conservation Biology-Asia Meeting.

Sukmantoro W. dan Agusrin MY. 2017. Seri Modul WWF Indonesia: Modul MP2CE untuk Mitigasi Koflik Gajah-Manusia Terpadu. WWF Indonesia, Pekanbaru, Riau.

Tohir MR. 2018. Diversity and palatability of the tame Sumatran Elephant (Elephas maximus sumatranus) feeding trees in Elephant flying squad, Tesso Nilo National Park - Riau.) Forest conservation and ecotourism department, Forestry Faculty, Bogor Agriculture Institute, Bogor. [Indonesian]

WWF Indonesia. 2014. WWF calls government to immediately investigate Sumatran Elephant death cases. https: //www.wwf.or.id/en/?35122/Pemerintah-Harus-Segera-TuntaskanKasus-Kematian-Gajah-Sumatera. [Indonesian] 